\title{
Peningkatan Perilaku Hidup Bersih Dan Sehat Dan Pemanfaatan Tanaman Obat Keluarga/Toga Menuju Desa Eduwisata
}

\author{
Titiek Hidayati ${ }^{1}$, Indrayanti ${ }^{2}$ \\ 1. Pendidikan Doker. Fakultas Kedokteran dan IImu KesehatanUniversitas Muhammadiyah Yogyakarta, Tamantirto, Kasihan Bantul, \\ Indonesia \\ ${ }^{2}$ Pathology Anatomy Department, Fakultas Kedokteran dan Ilmu Kesehatan,Universitas Muhammadiyah Yogyakarta, Tamantirto, Kasihan \\ Bantul, Indonesia \\ Email: hidayatifkumy@yahoo.co.id. \\ DOI: 10.18196/ppm.39.104
}

\begin{abstract}
Abstrak
Desa Bokoharjo merupakan salah satu desa tujuan wisata di DIY karena memiliki 3 situs candi. Selain potensi desa wisata juga memiliki potensi tanaman obat yang melimpah namun keluarga dan masyarakat belum banyak mengetahuinya dan memanfatkannya. Beberapa permasalahan Desa Bokoharjo sebagai desa tujuan wisata yaitu kebiasaan negatif dari pengunjung seperti membuang sampah, merokok, kinerja karang taruna, kader sehat, dan paguyuban pengrajin jamu belum optimal, potensi lahan kosong pekarangan belum mampu dimanfaatkan dengan benar dan disinergikan dengan kebutuhan bahan baku jamu tsb. Serangkaian kegiatan telah dilakukan untuk meningkatkan pengetahuan dan keterampilan pengrajin jamu dan masyarakat, meningkatkan perilaku hidup bersih dan sehat pada para karang taruna dan PKK, meningkatkan upaya dan tata kelola program promosi kesahatan PHBS dan TOGA. Kelompok sasaran utama adalah kader kesehatan, pengurus karang taruna dan pengurus PKK serta pengurus pengrajin jamu. Kelompok sasaran pendukung adalah warga masyarakat dan pengunjung wahana wisata di Desa Bokoharjo. Abstrak dibuat dalam bahasa Indonesia dan disusun dalam satu paragraf dengan jumlah kata tidak lebih dari 200 kata. Isi mencakup latar belakang, tujuan, metode, hasil, implikasi, dan simpulan.
\end{abstract}

Kata Kunci: Desa, Eduwisata, TOGA, PHBS

\section{Pendahuluan}

Desa Bokoharjo yang sebelumnya bernama kalurahan merupakan pemerintahan di bawah Distrik Kalasan terbagi menjadi tiga kalurahan, yaitu Kelurahan Marangan, Kelurahan Jobohan dan Kelurahan Prambanan. Luas wilayah Bokoharjo adalah $550 \mathrm{Ha}$, dengan pembagian 13 dukuh menurut wilayah padukuhan yaitu Pulerejo, Klurak Baru, Kranggan, Gatak, Ringinsari, Dawung, Cepit Marangan, Majasem, Jobohan, Pelemsari, Jirak dan Jamusan.

Pemerintah dan masyarakat Desa Bokoharjo menggunakan strategi utama yaitu "Pembangunan yang berbasis pada masyarakat dengan peran serta kelembagaan dan bertumpu pada kondisi kehidupan yang penuh kegotongroyongan serta kebersamaan." Program pembangunan Desa Bokoharjo mengutamakan upaya mengutamakan warga miskin, mengembangkan potensi masyarakat dan kewilayahan, kebencanaan, infrastruktur padukuhan dan pemberdayaan masyarakat mendukung desa wisata dan pengelolaan tanaman obat.

Kondisi geografi dan klimatologi daerah tersebut mendukung keberadaan berbagai jenis tanaman obat seperti sereh, pegagan, jahe, temulawak, kumis kucing, sukun, coklat, pare, mengkudu, sirsat, dan kapulogo tumbuh dengan baik di Desa Bokoharjo, termasuk Dukuh Klurak Baru. Potensi tanaman obat adalah memiliki kandungan flavonoid, polifenol, dan alkaloid. Kandungan tersebut bersifat antioksidatif dan imunomodulator, sehingga meningkatkan imunitas dan menghambat proses degeneratif. Sebagian besar penduduk Desa Bokohardjo berpendidikan sekolah dasar. Sebagaimana desa yang lain, Desa Bokohardjo mempunya kondisi sosial ekonomi menengah, dimana sebagian besar warga adalah sebagai petani dan pekerja. Petani tanaman obat di desa berkumpul dalam satu organisasi yaitu kelompok tani.

Namun peran kelompok tani belum optimal. Salah satu peluang untuk memperbaiki kondisi sosial ekonomi dan kesehatan sesuai dengan kondisi dan potensi lokal adalah mengembangkan 
TOGA sebagai salah satu komoditi rumah tangga. Setiap keluarga rata-rata memiliki pekarangan yang cukup luas untuk area penanaman tanaman obat keluarga (TOGA) namun lahan pekarangan belum dioptimalkan untuk TOGA.

Tanaman TOGA memiliki kandungan zat aktif dengan aktivitas sebagai antioksidan dan imunomodulator, suatu aktivitas biologis yang dibutuhkan untuk pencegahan dan penghambatan peningkatan penyakit degeneratif. Berdasarkan permasalahan yang ada maka program pemberdayaan masyarakat yang dilakukan bertujuan meningkatkan kesadaran dan keterampilan dalam memanfaatkan TOGA melalui pelatihan pembuatan minuman kesehatan menggunakan bahan tanaman obat keluarga.

\section{Metode Pelaksanaan}

Pemberdayaan masyarakat ini dilaksanakan pada tahun 2020 di Dukuh Klurak Baru, Desa Bokoharjo. Pemberdayaan ini menggunakan beberapa pendekatan dan metode intervensi untuk mencapai tujuan dan target yang telah ditetapkan. Pelaksanaan program pemberdayaan dilakukan oleh pelatih terdiri para dosen dan mahasiswa sebagai fasilitator dan pendamping Pemberdayaan Masyarakat. Tim pelaksana telah memenuhi persyaratan dan memiliki beberapa sertifikasi kompetensi serta telah dibekali menjadi fasilitator program pemberdayaan masyarakat. Program intervensi untuk pemberdayaan masyarakat ini telah mendapatkan izin dari pemerintah desa dan dikuatkan dengan adanya surat kesepakatan bersama dengan pimpinan dukuh.

Pelaksanaan program pemberdayaan masyarakat ini menggunakan sarana administrasi berupa lembaran angket untuk survei atau form pengambilan data, alat perekam gambar atau aktivitas untuk mendokumentasikan hasil observasi, media ajar, bahan ajar, alat peraga, bahan untuk pembuatan, mesin dan alat untuk pembuatan teh dan kantong bungkus teh serta karton untuk membuat kemasan.

Tahapan kegiatan pemberdayaan masyarakat ini adalah sebagai berikut:

\section{Persiapan dan Pembekalan Tim Pemberdayaan.}

Tim fasilitator dan pendampingan masyarakat yang berperan sebagai fasilitator dan pendamping masyarakat sasaran, terdiri dari dosen dan mahasiswa. Tim pelaksana terdiri dari 2 kelompok dengan masing-masing kelompok bertanggung jawab terhadap satu dusun. Setiap kelompok tim pelaksana terdiri dari 3 anggota mahasiswa. Tim pelaksana sebelum dilibatkan dalam program pemberdayaan masyarakat, diberi pelatihan sebagai fasilitator program pemberdayaan masyarakat selama satu minggu. Materi pelatihan sebagai fasilitator meliputi materi tentang aspek keilmuan manfaat dan materi tentang aspek keterampilan teknis. Materi pelatihan telah disiapkan oleh tim trainer dari dosen.

\section{Tahap Perencanaan dan Pengembangan Program}

Pada tahap perencanaan, tim mengidentifikasi masalah dan menetapkan prioritas masalah dengan melakukan observasi lapangan dan wawancara dengan tokoh masyarakat untuk mengetahui masalah dan prioritas masalah menurut masyarakat dan tokoh masyarakat, kemudian melakukan analisis dan menetapkan prioritas masalah dilanjutkan dengan pengembangan rencana aksi pemberdayaan kelompok sasaran. Berdasarkan hasil pengamatan langsung di lapangan, deskripsi wilayah, rencana program pembangunan wilayah, dan permasalahan yang ditemukan di lokasi, serta masukan-masukan dari dewan pakar maka disusunlah rencana program, yaitu "pelatihan pembuatan teh kesehatan. Adapun penjabaran dari rencana program pelatihan pemberdayaan masyarakat adalah sebagai berikut:

1.Rencana Penyelenggaraan Sosialisasi Program.

Kegiatan sosialisasi dilakukan dalam bentuk penyuluhan tentang jenis dan manfaat TOGA. 
2. Pengembangan Rencana Pelaksanaan Pelatihan.

Setiap pelatihan memiliki tujuan pembelajaran spesifik disertai dengan modul yang sesuai. Telah dikembangkan beberapa modul pelatihan untuk pelaksanaan program ini antara lain modul pelatihan pembuatan sediaan minuman kesehatan. Selain itu, juga telah disusun modul untuk pelatihan pemasaran dan pembuatan kemasan sediaan minuman kesehatan (Kusumandari, 2016).

3.Tahap Pelaksanaan

Pada tahapan ini dilakukan program pemberdayaan dengan tahapan yaitu sosialisasi program. Kegiatan sosialisasi program dilakukan di dua tempat sesuai dengan kelompok sasaran kegiatan. Telah dilakukan sosialisasi program tentang pemanfaatan pekarangan dengan penanamana tanaman obat keluarga, manfaat tanaman obat keluarga secara ekonomi dan kesehatan serta pentingnya berperilaku hidup bersih dan sehat untuk meningkat status kesehatan dan taraf kesejahteraan keluarga. Sosialisasi program dilakukan di aula samping masjid.

Rencana kegiatan sosialisasi pelatihan pembuatan minuman kesehatan dan perilaku hidup sehat dalam bentuk penyuluhan dan dialog dengan warga. Adapun rincian kegiatan untuk mendukung sosialisasi program pelatihan tersebut adalah sosialisasi Kesehatan Program TOGA dan Covid 19, penyuluhan potensi tanaman, pelatihan budidaya tanaman lokal dan penyuluhan Good Manifacturing.

Pelatihan pembuatan minuman kesehatan, pelatihan dan workshop pembuatan minuman kesehatan dilakukan dengan pendekatan cara pembelajaran orang dewasa. Satu program pelatihan direncanakan untuk satu target keterampilan. Sarana dan prasarana serta media disiapkan sesuai dengan pencapaian target luaran keterampilan, proses pemberdayaan, dan pelaksaan program pemberdayaan dilakukan selama 30 hari.

\section{Hasil dan Pembahasan}

Pembentukan Kelompok Inti dan Pendukung sebagai Pelaku Utama (aktor) melalui FGD yang melibatkan seluruh masyarakat. Kelompok ini dibekali dengan pelatihan sehingga memiliki skill yang baik dalam memanfaatkan dan berbudidaya TOGA termasuk dalam tata kelola program promosi kesehatan dan ber-PHBS. Perencanaan dan perizinan pelaksanaan pelatihan telah dilaksanakan tentang tata kelola kegiatan dan pembuatan sediaan TOGA sesuai protokol Covid-19. Pembentukan tim promosi yang terdiri atas elemen pengurus wisata dan beberapa pemuda karang taruna yang memiliki akses dan mobilisasi cukup tinggi. Kelompok ini akan dilatih strategi promosi (paket) pelatihan promosi efektif.

Rencana program yang direncanakan pada fase persiapan prakegiatan sebagian besar dapat terlaksana sesuai jadwal yang sudah ditetapkan. Kegiatan pemberdayaan masyarakat dilaksanakan selama 30 hari. Beberapa kegiatan terlaksana dengan penyesuaian jadwal kegiatan masyarakat. Pelaksanaan program kerja yang telah terlaksana juga masih banyak mengalami kekurangan baik dari segi teknis maupun nonteknis antara lain kondisi sarana dan prasarana lingkungan yang kurang mendukung dan keterbatasan waktu. Uraian pelaksanaan program pelatihan pembuatan minuman kesehatan dan perilaku hidup sehat berdasarkan nilai kearifan lokal masyarakat dukuh. Jenis kegiatan sosialisasi dan pelatihan terdiri dari:

1. Melaksanakan sosialisasi tentang pemberdayaan masyarakat dalam mengangkat potensi tanaman lokal menjadi minuman kesehatan. Hasil dari kegiatan ini kepala desa dan ketua Dukuh Klurak baru mengetahui tentang pentingnya program pelatihan pembuatan minuman kesehatan dan manfaatnya bagi peningkatan kesejahteraan dan kesehatan masyarakat.

2. Pemeriksaan kesehatan dan tekanan darah serta sosialisasi perilaku hidup sehat dan manfaat minuman kesehatan pada warga. Jumlah peserta antara 20-30 warga. Hasil kegiatan ini masyarakat semakin tahu tentang gejala penyakit hipertensi dan DM, serta 
manfaat berolah raga serta manfaat mengkonsumsi minuman kesehatan.

3. Penyuluhan potensi tanaman sebagai minuman kesehatan. Hasil dari kegiatan adalah terjadi peningkatan pengetahuan masyarakat mulai usia anak sampai dewasa di Desa Beji tentang manfaat dan kegunaan kelor, pegagan, jahe, sereh, dan coklat untuk pemeliharaan kesehatan dan pencegahan penyakit

4. Penyuluhan Good Manufacturing Practice (GMP) dalam makanan. Hasil dari kegiatan adalah terjadi peningkatan pengetahuan masyarakat dewasa di Desa Beji tentang cara pengolahan makanan dan TOGA yang memenuhi standar kesehatan dan produksi yang baik

5. Menyelenggarakan kegiatan PHBS (Perilaku Hidup Bersih dan Sehat).

6. Melakukan pelatihan dan pendampingan pengolahan tanaman lokal daun pegagan menjadi minuman kesehatan untuk warga, pendampingan pengolahan tanaman daun kelor menjadi minuman kesehatan kelompok

7. Pelatihan budidaya tanaman lokal, pengemasan dan labeling, pelatihan pemasaran produk minuman kesehatan

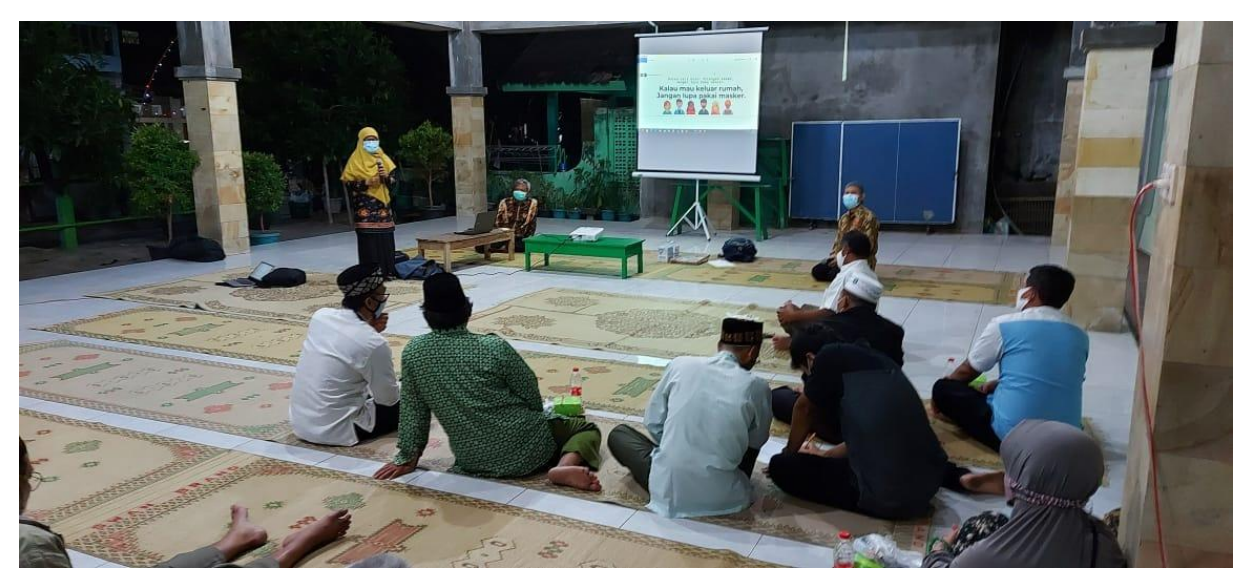

Keterangan gambar: Proses edukasi memberikan contoh selalu memakai masker

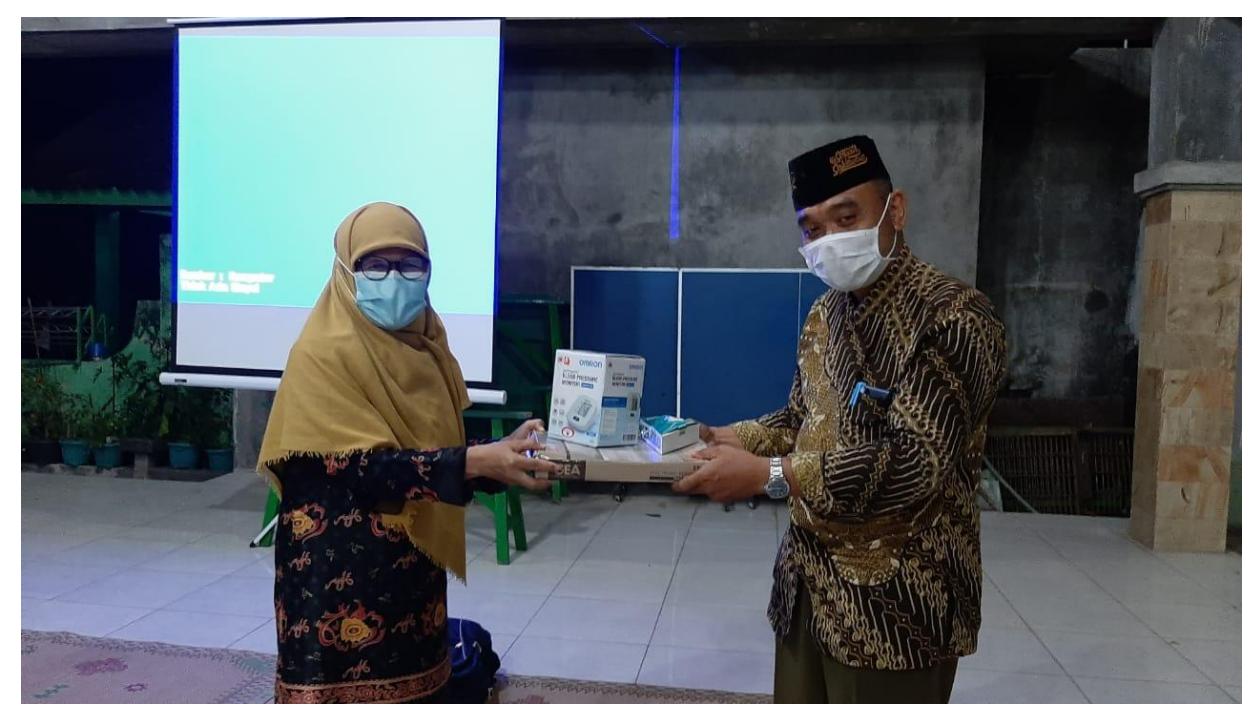

Keterangan gambar: Proses penyerahan alat pemeriksaan penyakit kronis

Beberapa kegiatan sosialisasi penyakit degeneratif (DM, hipertensi), perilaku hidup sehat, manfaat TOGA dan minuman kesehatan dilakukan pada semua kelompok masyarakat dari balita, anak, remaja, dewasa hingga lansia. Materi atau isi dan metode edukasi disesuaikan 
dengan dengan kelompok sasaran (Abu Talib et al., 2018). Menanamkan gaya hidup sehat dan pemanfaatan TOGA perlu dilakukan sejak dini terutama untuk pencegahan penyakit degeneratif Sutardi, 2017). Beberapa bentuk kegiatan sosialisasi adalah jalan sehat, senam sehat untuk semua kelompok umur, penyuluhan PHBS, pemutaran video 6 langkah cuci tangan menurut WHO pada anak SD dan TPA, serta remaja. Selanjutnya sosialisasi pemanfaatan TOGA dari tanaman lokal dan minuman kesehatan untuk semua kelompok umur, pengenalan gejala tanda dan cara pencegahan serta pemeriksaan kesehatan. Tidak terkecuali promosi kesehatan untuk meningkatkan kesadaran berperilaku hidup sehat dan mendorong masyarakat meningkatkan aktifitas fisik efektif menurunkan komplikasi hipertensi dan DM (Narain, Garg, and Fric, 2011). Terkait dengan osteoporosis, penyakit ini dapat didefinisikan sebagai suatu penyakit yang ditandai dengan berkurangnya massa tulang dan adanya perubahan mikro-arsitektur jaringan tulang yang berakibat menurunnya kekuatan tulang dan meningkatnya kerapuhan tulang, sehingga tulang mudah patah. Definisi lain, osteoporosis adalah kondisi tulang menjadi tipis, rapuh, keropos, dan mudah patah akibat berkurangnya massa tulang yang terjadi dalam waktu yang lama. Secara statistik, osteoporosis didefinisikan sebagai keadaan dimana Densitas Mineral Tulang (DMT) berada di bawah nilai rujukan menurut umur atau standar deviasi berada di bawah nilai ratarata rujukan pada usia dewasa muda. Sebelum terjadi osteoporosis, seseorang terlebih dahulu mengalami proses osteopenia, yaitu suatu kondisi hilangnya sejumlah massa tulang akibat berbagai keadaan. Penyakit ini dijuluki sebagai Silent Epidemic Disease, karena menyerang secara diam-diam, tanpa adanya tanda-tanda khusus, sampai si pasien mengalami patah tulang. Edukasi tentang pencegahan dan penanganan osteoporosis perlu dilakukan pada lansia (Fa et al., 2012).

\section{Simpulan}

Berdasarkan penilaian saat pelaksanaan pengabdian masyarakat dapat disimpulkan bahwa terjadi (1) peningkatan pengetahuan dan kesadaran masyarakat untuk berperilaku hidup sehat melalui olah raga dan jalan sehat, (2) peningkatan pengetahuan tentang manfaat TOGA, dan (3) peningkatan keterampilan dalam membuat minuman kesehatan masyarakat merasakan adanya manfaat program dan berharap diadakan tindak lanjut untuk di masa yang akan datang.

\section{Ucapan Terima Kasih}

Ucapan terima kasih dan penghargaan yang sebesar-besarnya diberikan kepada PPM UMY kepada pemberi dana dengan nomor kontrak PPM 031/PEN-LP3M/I/2020, Kepala dukuh Kluwar Baru, Takmir masjid, Desa Bokohardjo Krakalan dan seluruh aparat pemerintah desa yang telah memberikan fasilitas dan dukungannya selama kegiatan pengabdian dilaksanakan.

\section{Daftar Pustaka}

Abu Talib, I. F. et al. (2018) 'Community Empowerment through Rehabilitation and Reconstruction in Social Sector of Kuala Krai, Kelantan, Malaysia', Procedia Engineering. Elsevier B.V., 212(2017), pp. 294-301. doi: 10.1016/j.proeng.2018.01.038. American Diabetes Association [ADA]. (2017). Diagnosis and Classification of Diabetes Mellitus. Diabetes Care. Jan; 34(Suppl 1): S62-S69, doi: 10.2337/dc11-S062, PMCID: PMC3006051.

Codario, R. A. 2011. Type 2 Diabetes, Pre Diabetes, and The Metablic Syndrome. USA : Humana Press.

Fa, D. et al. (2012) 'Faktor Determinan Risiko Osteoporosis Di Tiga Provinsi Di Indonesia', Media of Health Research and Development, 20(2 Jun), pp. 91-99. doi: 
10.22435/mpk.v20i2Jun.787.

Fatimah Noor R., 2015, Diabetes Melitus Tipe II (review artikle), Lampung: Fakultas

Kedokoteran Universitas Lampung.

Kemenkes RI. (2014). PROFIL KESEHATAN INDONESIA. Jakarta: Kementrian Kesehatan Republik Indonesia.

Muthoharoh Ainun, 2017, Pengaruh Konseling Farmasis dan Pesan Motivatif Terhadap Perubahan Perilaku dan Kualitas Hidup Pasien Diabetis Mellitus Komplikasi Hipertensi

Rawat Jalan Poliklinik Penyakit Dalam Di RSUD Panembahan Senopati, Bantul (thesis), Universitas Ahmad Dahlan, Yogyakarta.

Mansjoer, A., dkk. 2005. Kapita Selekta Kedokteran. Jakarta: Media Aesculapius.

Palaian, Subish \& Prabhu, Mukhyaprana \& Shankar, P Ravi,2006, Patient counseling by pharmacist - A focus on chronic illness. Pakistan journal of pharmaceutical sciences. 19. 65-72.

Rantucci, M.J. 2007.Komunikasi Apoteker-Pasien: Panduan Konseling Pasien(Edisi 2). Penerjemah : A.N. Sani. Jakarta: Penerbit Buku Kedokteran EGC.

Sammulia Suci F, Fita Rahmwati, Tri Murti Andayani, 2016, Perbandingan Pill Box Dan Mediaction Chart Dalam Meningkatkan Kepatuhan Dan Outcome Klinik Geratri Di Kota Batam, Fakultas Farmasi, Universitas Gadjah Mada, Yogyakarta.

Smeltzer, S. C., \& Bare, B. G. 2001. Buku Ajar Keperawatan Medikal-Bedah Brunner dan Suddarth Volume 2, Edisi 8. Terjemahan oleh Agung Waluyo, dkk. Jakarta: EGC.

Trihono, Partini P et al. (2018) Kidney Disease Profiles Among Adolescents In Indonesia, Acta Med Indones-Indones J Intern Med . 